\title{
3. The United States: crisis leadership in times of transition
}

\author{
Isaac Ijjo Donato
}

\section{Going down: the escalation of the sub-prime mortgage crisis}

The US financial crisis, which has since become global, originated in 2007 when the US mortgage industry began to perform poorly (Kregel 2008). For the past decade, the United States has pursued aggressive supply-side economic policymaking, emphasising low interest rates, low taxes and highly deregulated financial markets (Uchitelle 2008). This created a boom in which money became cheap, and positive forecasts on the housing market encouraged financial institutions and prospective homeowners, respectively, to lend and borrow exceedingly (Obama 2009b). Altogether, this gave rise to sub-prime lending, whereby banks lent money to even those with poor credit histories (Chomsisengphet and Pennington-Cross 2006). When the housing bubble finally burst in 2007, sub-prime mortgage loans, which by this time had grown substantially and had given rise to a lucrative secondary mortgage market (mortgage hedge market), were the most adversely affected (Kregel 2008).

The mortgage crash kicked off a market wind-down beginning, prominently, with Bear Stearns (Bear), a Wall Street investment bank. Earlier the previous year, Bear had implicated itself in the sub-prime mortgage market by committing more than $\$ 3$ billion dollars to bail out one of its hedge funds that had bet heavily on the sub-prime loans (Burrough 2008). On the morning of 10 March 2008, a rumour about Bear's liquidity problems began to spread in the financial market (PBS Frontline 2009). An unprecedented stock sell-off ensued, driving the bank's stock down 47 per cent (Irwin and Tse 2008). Six days later, despite Federal Reserve and Treasury attempts to save the eighty-five-year-old investment bank, Bear ran out of its $\$ 18$ billion cash reserve and collapsed (Irwin and Tse 2008).

Months later, in September 2008, Fannie Mae and Freddie Mac, the two federally backed mortgage lending firms that had also speculated heavily on the returns from their various mortgage investments, began to falter due to rising defaults on home mortgage repayments (Irwin and Tse 2008). The Bush Administration reacted to this by firing their managements and nationalising the banks (KDKA-TV 2008). In the same month, three other major US financial institutions-Lehman Brothers, Washington Mutual Inc. and American International Group — had either filed for bankruptcy or failed (KDKA-TV 2008). 
This series of bank collapses was a strident manifestation of an economy in full-blown crisis, threatening the foundations and lifeblood - the financial and credit markets - of the US and world economies. On Thursday, 18 September 2008, Treasury Secretary, Henry Paulson, and Federal Reserve Chairman, Ben Bernanke, painted a bleak picture of the cascading crisis in a hastily convened emergency meeting involving the heads of key US financial institutions and political figures. Respectively, they warned, 'unless you act, the financial system of this country and the world will melt down in a matter of days' and 'if we don't act tomorrow, we won't have an economy on Monday' (PBS Frontline 2009).

Boin et al. (2009) observe from the Thomas theorem that it is not the events on the ground, but their public perception and interpretation that will determine their potential impact. In the case of the United States in September 2008, however, the country was in crisis at all levels: reality, perception, emotion and rhetoric. While the downturn presented policymakers with huge challenges to manage, it also opened political opportunities to exploit - at least for some of them. Drawing on the crisis-framing model of Chapter 2, this chapter studies how US Presidents George W. Bush and later Barack Obama, Treasury Secretaries Henry Paulson and his successor, Timothy Geithner, and the Federal Reserve Chairman, Ben Bernanke, framed the unfolding crisis and its policy and political implications. Some of these actors were predominantly in 'damage-control' mode; others were at times perhaps drawn towards 'opportunity exploitation'. In keeping with the analytical approach of this volume, this chapter also examines how these framing efforts were publicly received by the media and the public, and, thus, to what extent the various elite framing efforts resonated with (parts of) their intended audiences.

It is important to understand the context in which the leaders under study operated. As the meltdown was transforming financial markets, regime change was transforming politics in the United States. President Bush's tenure was due to end in early 2009 and Democrat candidate, Barack Obama, and Republican John McCain were contending for the presidency in the election due in November 2008. For the two candidates, and the incumbent president, the crisis played into their political manoeuvring. Although the scope of this volume excludes non-executive leaders, occasional reference will be made to the continuing election struggle, especially given that the policy debate between the two contestants reflected a strong partisan-Republican and Democrat - theme, which greatly influenced the political context in which Bush and later Obama operated as presidents when talking about the crisis.

\section{Methodological considerations}

This chapter is structured in fours parts. Parts one to three will analyse speech acts of the President, the Treasury Secretary and the Federal Reserve Chairman. 
For each leadership position, four speech acts made by office-holders between April 2008 and March 2009 will be analysed. Given that there was a change of administration during this period, the analysis will reflect this by covering two speeches each by the former and current presidents and treasury secretaries.

Each of these speeches has been selected on the basis of it being delivered in response to a key development in the unfolding of the crisis in the United States. Time lapses have also been factored into the selection of the speech acts, in order to measure the evolution of the framing attempts by these leaders. To place these speeches in context and gain a sense of the public opinion at the time of these speeches, public opinion poll data published by Gallup Poll alone or in association with USA Today have been collected. In addition to the public opinion data, three US newspapers of national and international stature form the basis of the media response: The Wall Street Journal, The New York Times and The Washington Post. The ideological bent of the first is more towards the conservative end, whereas the other two are more towards the progressive end. The New York Times has a daily circulation of more than million readers, The Wall Street Journal has more than two million and The Washington Post more than 600000 (Audit Bureau of Circulations 2009). For each speech act, a sample of articles was examined, including news reports, editorials and op-ed pieces relevant to the financial crisis published one or two days after the speech.

How the relevant leaders' framing attempts evolved over time in response to the unfolding events of the crisis - nationally and globally-is discussed in relation to each leadership position, based on an examination of the key speech acts. Four speech acts are analysed for each leadership position. As such, the analysis of this evolution was limited to only two speeches for each office-holder, bar Bernanke. Finally, part four of the chapter interprets the findings. At this point, the extent to which the meaning-making efforts of these actors relate to one another is examined, and the main 'battlegrounds' of the 'framing contests' surrounding the crisis are pinpointed.

\section{Box 3.1 The United States' financial crisis trajectory, March 2008 - March 2009}

Io March 20o8: Bears Stearns' liquidity problems start, putting the bank on course to collapse seven days later.

I4 March: Federal Reserve officials find Bear is 'systemically' connected with the wider financial markets, meaning its failure could risk the collapse of the whole financial system. Federal Government rescue efforts begin.

2 April: Federal Reserve Chairman, Ben Bernanke, testifies before Congress, warning that recession in the United States is possible. 
Io April: The Senate passes a bipartisan measure aimed at boosting the housing market.

30 April: The Federal Reserve cuts interest rates to the lowest point in nearly four years.

II July: IndyMac Bank fails.

I2 July: Treasury Secretary, Henry Paulson, successfully seeks power to take over Fannie Mae and Freddie Mac, the two government-sponsored mortgage-lending entities.

3o July: President Bush signs a housing bill, allowing homeowners who cannot afford repayments to refinance access to more affordable government-backed loans.

7 September: The Bush Administration nationalises Fannie Mae and Freddie Mac.

I2 September: Lehman Brothers requests a bailout, but Paulson decides not to bail the firm out, citing moral hazard.

I4 September: Merrill Lynch sells itself to Bank of America and Lehman Brothers files for bankruptcy, after it fails to find a buyer in an increasingly nervous market.

I6 September: The Federal Reserve changes course and spends \$84 billion to bail out American International Group (AIG), the largest insurance firm in America.

I8 September: Paulson proposes a $\$ 700$ billion plan to buy toxic assets from America's biggest banks.

25 September: Washington Mutual Bank fails.

29 September: Congress rejects Paulson's proposal.

3 October: Congress approves Paulson's revised plan.

28 October: The Federal Reserve cuts its lending rate to 1 per cent.

4 November: Barack Obama is elected President.

I4 November: Leaders of 20 major economies gather in Washington, DC, to discuss coordinated emergency action to address the financial crisis.

I6 December: The Federal Reserve cuts its interest rates again - to nearly zero.

20 January 2009: Barack Obama is sworn in as the forty-forth President of the United States. 
26 January: The Senate confirms Timothy Geithner as Treasury Secretary, succeeding Paulson.

Io February: Geithner outlines a new, sweeping overhaul and expansion of the government's rescue effort.

I7 February: Obama signs a $\$ 787$ billion package to revive the economy. I8 February: Obama announces a $\$ 275$ billion plan to help financially struggling families to refinance their mortgages.

I9 February: Obama orders the nation's 19 largest banks to undergo a 'stress test' to help bolster confidence in the bailout plan.

23 March: Geithner lays out a detailed version of his 10 February rescue plan.

24 March: Obama and the Federal Reserve seek to expand the Federal Government's power to seize control of troubled financial institutions deemed too big to fail.

\section{Crisis development and elite rhetoric in the United States}

\section{From crisis to opportunity: Presidents Bush and Obama}

The financial and economic meltdown that took place in 2008-09 affected Presidents Bush and Obama very differently. Bush was serving his last term in office and, by mid 2008, he was well and truly a lame-duck president. His steadily declining approval rating had hit a new low of 32 per cent by 14 March 2008, and never really recovered (Gallup Organization 2008). On the other hand, by the end of 2008, Obama had been voted into office on a popular platform of change. His approval rating was as high as 69 per cent at the time he assumed office (Jones 2009). What for Bush was yet another nasty crisis eating away at his political capital, and possibly his place in history, to Obama became a window of opportunity to dramatise his ability to bring a fresh approach and renewed vigour to the presidency at a time of national despair. Bush's challenge was to avoid being labelled as a modern-day Herbert Hoover (whose presidency was destroyed by the impact of the 1929 Wall Street crash); Obama's bid was to become a modern-day Franklin D. Roosevelt (whose 'New Deal' gave Americans hope and pioneered Keynesian economic policies that would become the norm after World War II).

\section{March 2008: President Bush's 'business as usual'}

By 14 March 2008, the financial crisis had taken a critical turn; banks on Wall Street were fear-stricken after Bear Stearns' liquidity problems (PBS Frontline 2009). In a speech he delivered to the Economic Club of New York four days after Bear's liquidity troubles began and two days before the bank collapsed, 
the President steered clear of using the word 'crisis' to describe the gathering storm. The closest he came to doing so was by describing the situation as a 'rough time' for the economy - an economic downturn and a slowdown, which he explained were inherent periodic features of the free-market system. In a free market, he claimed, 'there is going to be good and bad times... ups and downs, [which is] how markets work'. For Bush, there was no crisis; it was business as usual and his purpose in the speech was to downplay the problem and its extent.

The President was intent on alleviating public anxiety and rekindling faith in the American economy. 'I am coming to you as an optimistic fellow,' he told the club members, adding that he believed America's was a resilient economy, which would continue to grow, because its foundations were solid. He added that the government had recognised the market slowdown early and had taken action in the form of policies designed to spur growth and strengthen oversight of the mortgage industry. These policies included a tax package targeting 130 million households to boost consumer spending through a newly created Federal Housing Administration (FHA Secure) to help facilitate the prevention of unnecessary foreclosures.

Despite these assurances and initiatives, Bush's speech did not resonate in the media. The three newspapers surveyed for this article mostly disagreed with his claims regarding the origins and the severity of the situation and his proposed policy package (see the online appendix at <http://global financialcrisis.wetpaint.com/>). The few who welcomed the President's speech expressed a sigh of relief for Bush having at least acknowledged, though not fully, that there were problems with the economy (Thomas 2008). The main thrust, however, was criticism of Bush's alleged lack of leadership and his deliberately steering clear of the word 'recession', which by this time the United States was already in, according to key economists (Baker 2008; Thomas 2008). In none of the press reactions to the speech surveyed was there any statement of support for the President (Table 3.1). A host of reasons contributed to the lack of positive public response to the President's speech, but perhaps the overarching one was Bush's record low popularity on the wings of the nasty war in Iraq and his failure as national crisis manager during Hurricane Katrina. By 2008, crisis-management competence had long ceased to be a political selling point for a president who had once enjoyed a strong and comparatively long boost in popularity after the 9/11 crisis (Gallup Organization 2008; see 't Hart et al. 2009). 


\begin{tabular}{|l|l|l|l|}
\hline & Causality & Proposed policy & $\begin{array}{l}\text { Support for } \\
\text { speaker }\end{array}$ \\
\hline Agrees & & 2 & \\
\hline Disagrees & 5 & 3 & \\
\hline $\begin{array}{l}\text { No comment/ } \\
\text { neutral }\end{array}$ & 3 & 3 & 8 \\
\hline
\end{tabular}

\section{Table 3.1 Media response to President Bush's 14 March 2008 speech}

Clearly, President Bush had pre-existing credibility deficits in the face of the American public, even before the global financial crisis started to unfold (Boin et al. 2009:78). His understated admission that the American economy was going through a rough time served only to confirm this, certainly among media outlets long critical of his record. For example, in an editorial entitled 'George speaks, badly', a New York Times columnist derided Bush's poor articulation, inept understanding of the subject matter, lateness and, above all, incapacity to perform as a leader in crisis (Collins 2008).

\section{September 2008: Bush's acknowledgment of deep problems}

By September, President Bush had changed his tone. He delivered a prime-time address to the nation on the American economy and the proposed bailout on 24 September 2008. The speech came after it had become exceedingly clear that the American economy was in deep crisis. Three particular moments were noteworthy. In addition to Bear Stearns, seven other major banks had collapsed (FIDC 2009). The crisis was going global fast, and reached well beyond the financial and housing sectors alone. It became apparent that the US Government's (Paulson's and Bernanke's in particular) hitherto piecemeal efforts of bailing out one bank at a time had failed. So the Treasury Secretary and the Federal Reserve Chairman went to the President to ask Congress to release money for a wholesale rescue of the country's financial market (PBS Frontline 2009).

At this time, denial was no longer a credible option. In terms of the crisis-exploitation model of Chapter 2, Bush therefore shifted from type-1 to type-2 rhetoric, acknowledging that the entire economy, not just the housing market and the financial sectors, was in trouble. He admitted that America's economy was 'in the midst of a serious financial crisis', which he depicted as 'a moment of great challenge'.

His account of the causes of the crisis emphasised exogenous factors, particularly market forces (mortgage defaults, excessive risk taking and the influx of foreign capital) and unscrupulous financial trading practices. He said that many lenders approved loans for borrowers without carefully examining their ability to pay and many borrowers took out loans larger than they could afford. 
In terms of his proposed response to the crisis, Bush invoked the same 'can-do' crisis-management rhetoric he had used successfully after 9/11, but which had backfired badly after Katrina, to reassure Americans that the government was in control. He asserted that Americans had good reasons to be confident of their economic strength, insisting that despite 'market corrections' and instances of abuse, democratic capitalism remained the best system ever devised-because it had given the American economy the flexibility to absorb shocks, adjust and bounce back.

This time, the media was somewhat more attentive and its opinions were more mixed. The acknowledgment of severity was welcomed, and a few voices agreed with the President's causality claims, but most did not. Of the press articles surveyed, a significant majority disagreed with Bush's proposed policies (Table 3.2). Notwithstanding that, a Gallup Poll conducted a week later showed that the $\$ 700$ billion bailout Bush had proposed in the speech was well received by the public (Saad 2008). Paradoxically, the President's overall job approval rating plunged towards its lowest level-27 per cent - since his first speech in March (Jones 2008).

\begin{tabular}{|l|l|l|l|}
\hline & Causality & Proposed policy & $\begin{array}{l}\text { Support for } \\
\text { speaker }\end{array}$ \\
\hline Agrees & 2 & 4 & \\
\hline Disagrees & 4 & 8 & \\
\hline $\begin{array}{l}\text { No comment/ } \\
\text { neutral }\end{array}$ & 6 & & 12 \\
\hline
\end{tabular}

Table 3.2 Media response to Bush's 24 September 2008 speech

\section{February 2009: President Obama blames Wall Street}

Having assumed office with all the energy of a new president enjoying an extraordinary political honeymoon, Obama arguably took the crisis as an opportunity to drive the last nail in the coffin of Bush's legacy. In his first key speech on the economy and executive pay, delivered on 4 February 2009, Obama took a type-3 stance, describing the situation as 'an economic crisis unlike any other we have faced in our lifetime... a crisis of falling confidence and rising

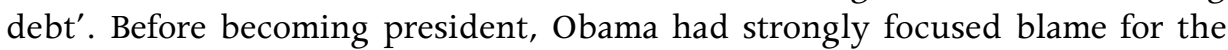
meltdown and its persistence on the Bush Administration's fiscal and regulatory policies, which he had promised to change (Obama 2008). Now that he was in office, his blame focus had changed somewhat. The President's main targets were the executives in the financial institutions that had received government rescue funds.

The President remained in the offensive type- 3 mode, with his aim now to change the remuneration regime that had helped trigger the crisis. He explained that 
the crisis had been years in the making and was brought about by a corporate culture that disregarded risk, cost and consequences by offering perverse incentives structures to traders and executives. Obama focused blame on Wall Street and utilised the opportunity to introduce his policy, the American Recovery and Reinvestment Plan, one aspect of which was reforming executive remuneration regimes. Through that, the President aimed to cap at $\$ 500000$ the pay of executives in firms receiving support from the government's rescue fund.

Media reaction to the President's speech was mixed (Table 3.3). The bulk of the press coverage sampled made no comment about the President's causality claims. More than half agreed with the salary cap aspect of the policy; and nearly all made no comment about support for the President. A Gallup Poll taken four days after the speech, however, put Obama's approval rating at 63 per cent (Jones 2009).

\begin{tabular}{|l|l|l|l|}
\hline & Causality & Proposed policy & $\begin{array}{l}\text { Support for } \\
\text { speaker }\end{array}$ \\
\hline Agrees & 2 & 7 & \\
\hline Disagrees & & 6 & \\
\hline $\begin{array}{l}\text { No comment/ } \\
\text { neutral }\end{array}$ & 12 & 1 & 14 \\
\hline
\end{tabular}

Table 3.3 Media response to Obama's 4 February 2008 speech

\section{February 2009: Obama's address to Congress}

Obama showed his most strident type- 3 posture in an address to the Joint Houses of Congress on the 24 February 2009. Acknowledging the recession up front, the President told the nation that the state of our economy is a concern that rises above all others...you do not need a long list of statistics to know that our economy is in a crisis'. He explained that the American economy had not fallen into decline over night and the problems had not started when the share and stock markets collapsed. The problems, Obama claimed, had roots in expensive health care, poor education and dependence on foreign energy sources - the challenges that went unmet while Americans spent more money and piled up more debt.

In accounting for the crisis, Obama implicitly attributed a significant portion of blame to the previous administration, although, as politicians often do, he explicitly denied doing so. Apart from the few lines of therapeutic rhetoric such as 'we will rebuild', 'we will recover and the USA will emerge stronger than before' - lines somewhat reminiscent of Bush's - Obama prescribed major reforms of health care, education and energy as a way out of the crisis. Constituting the thrust of the American Recovery and Reinvestment Plan, these reforms were to 
jump-start job creation, save existing ones, restart lending, bring the government deficit down and grow the economy.

Obama underlined his policy appeal with a sweeping use of historical analogies; he told Americans:

History reminds us that, at every moment of economic upheaval and transformation, this nation has responded with bold action and big ideas...In the midst of civil war, we laid railroad tracks from one coast to the other that spurred commerce and industry...From the turmoil of the Industrial Revolution came a system of public high schools that prepared our citizens for a new age...In the wake of war and depression, the GI Bill sent a generation to college and created the largest middle-class in history.

Obama's rhetoric proved popular with the papers and the public. Most of the press coverage studied here supported the President's causality claims. The overwhelming majority agreed with his policy propositions and an equal amount expressed support for the President (Table 3.4). After his approval rating had dropped to 59 per cent two days earlier, a Gallup Poll taken on the day of the speech found the President's approval rating had spiked back up to 67 per cent (Jones 2009).

The result must be interpreted with some caution. Obama was elected to the presidency on a strong platform of change in the three key areas of energy, education and health care (Obama 2008). The positive response was arguably being expressed at least in part for Obama having acted on his election promises rather than his articulation of novel measures addressing the economic crisis. Indeed, only 41 per cent of people interviewed said they now had more confidence in Obama's plan to fix the economy (Morales 2009).

In comparison, Obama's crisis-framing effort in this subsequent speech changed quite significantly from that in his first. Given that no significantly seismic development in the unfolding crisis happened between his two speeches studied here, the change in his rhetorical pitch could be attributed to the particular policy aspect he sought to introduce through each speech. Obama's framing, especially his naming and explaining of the crisis in the first speech, bore a semblance to his predecessor's. This was mainly because his main targets were the corporate executives, whose pay-outs were a hot topic in the news at that time. The 24 February speech had a wider explanatory scope, setting up the audience for a much wider suite of policy measures. 


\begin{tabular}{|l|l|l|l|}
\hline & Causality & Proposed policy & $\begin{array}{l}\text { Support for } \\
\text { speaker }\end{array}$ \\
\hline Agrees & 3 & 7 & 7 \\
\hline Disagrees & & 1 & \\
\hline $\begin{array}{l}\text { No comment/ } \\
\text { neutral }\end{array}$ & 4 & & 1 \\
\hline
\end{tabular}

Table 3.4 Media response to Obama's 24 February 2009 speech

\section{From reassurance to repair: Treasury Secretaries Paulson and Geithner}

Henry Paulson, a former chief executive officer of Goldman Sachs, had come to the Treasury job in the Bush Administration with intimate knowledge of the working of the financial markets outside government and the trading behaviours of those on Wall Street. His successor, Timothy Geithner, had been the president of the Federal Reserve of New York during the Bush Administration. He had worked with Bernanke and Paulson - albeit in vain - to avert Bear Stearns' demise in March 2008, and all the way thereafter until Obama appointed him to head the Treasury. Geithner had intimately experienced the crisis from a senior policymaker's perspective. He had observed Paulson respond to the crisis and saw part of it backfire - not in the least on Paulson himself. With these contexts in mind, this part of the chapter looks at how the two secretaries named, explained, accounted for and proposed to manage the unfolding crisis.

\section{March 2008: Secretary Paulson's innuendo}

Paulson delivered his first major speech of the period under study barely two weeks after he had witnessed the collapse of a nearly one-century-old financial institution, Bear Stearns. Even though the speech was about the problems in financial and housing markets, the Treasury Secretary steered clear of calling a spade a spade. He described the events as 'financial market stress', 'turbulence' and 'bumps', which he explained were a result of de-leveraging and re-pricing of risk (Paulson 2008a). Precipitated by unsustainable home price appreciation, these reduced access to short-term funding and liquidity and created turmoil in the American capital markets.

Like Bush at the time, Paulson was painting an image of the American economy as being essentially sound, albeit experiencing short-term 'market upheaval'. For Paulson, it was business as usual; hence, there was no need to account for the problem, apart from making clear the causes of the current turbulence, which, again, he sought within the market, not in government regulation or policy. In the speech, Paulson did not announce specific measures to address the market turbulence, though he noted that efforts were being made to limit the impact of the turbulence on the real economy, which was the highest priority. 
He said such efforts to insulate the economy would be achieved through increasing the availability of affordable mortgage financing through the Federal Reserve's temporary lending facility.

Media commentators and the American public remained largely indifferent to Paulson's rhetoric (Table 3.5). Most articles expressed no agreement or disagreement with his causality claims and none expressed support or lack thereof for the secretary. The lack of a more marked response was perhaps due to the highly technical content of the speech, combined with the fact that in times of crisis it is the President, and not the Treasury Secretary, who is the chief economic storyteller in the country (Wood 2007:63-108). Some writers, however, did agree with the Treasury's policy proposition, especially the establishment of the FHA Secure initiative. Those who expressed support thought FHA Secure would revitalise the housing market and prevent foreclosures (Paletta 2008).

\begin{tabular}{|l|l|l|l|}
\hline & Causality & Proposed policy & $\begin{array}{l}\text { Support for } \\
\text { speaker }\end{array}$ \\
\hline Agrees & & 2 & \\
\hline Disagrees & & & \\
\hline $\begin{array}{l}\text { No comment/ } \\
\text { neutral }\end{array}$ & 8 & 6 & 8 \\
\hline
\end{tabular}

Table 3.5 Media response to Paulson's 26 March 2008 speech

\section{November 2008: Paulson's switch to crisis mode}

Seven months after Paulson made his speech to the US Chamber of Commerce, and with more banks having collapsed, it had become clear that the problems were escalating well beyond the mortgage market and financial services sector. This was an economy-wide crisis that was rapidly going global. At the time, Paulson requested and was granted $\$ 700$ billion to execute a full-scale rescue operation for the financial services sector. It was therefore inevitable that Paulson's framing had shifted from business as usual to acknowledging the threat for what it was. He acknowledged that the US economy was in crisis (Paulson 2008c). In fact, in his testimony to Congress on the implementation of the Emergency Economic Stabilisation Act, on 18 November 2008, Paulson mentioned the word 'crisis' at least nine times. He described the financial crisis as one of a magnitude and unpredictability that he and his peers in the sector had never dealt with - in their lifetimes.

Apart from describing the manifestation of the extent of the damage the crisis had done already in statistical terms, Paulson acknowledged that the financial system had gone belly-up and now the economy was in a system-wide crisis. In his testimony, he provided no causal explanation for the crisis and he did not 
accept or deny responsibility for its escalation. Rather like President Bush, he continued to assure Americans that he had confidence in the economy's regulators and markets. At the same time, he made it clear that there was no set script for responding to a level of turmoil they had never faced before. Referring to the bailout, he added that the administration would adjust its strategy to reflect the dynamics of the crisis, and he urged Congress to work with it to stabilise the financial system.

Media reaction to the Treasury Secretary's speech was more negative than positive. No-one voiced agreement with the secretary's causal claims or his proposed stimulus package. Some commentators thought the package was fundamentally misguided (for example, Washington Post 2008). While most were neutral about Paulson himself, one journalist criticised the 'erratic performance' of the secretary in the crisis (New York Times 2008).

\begin{tabular}{|l|l|l|l|}
\hline & Causality & Proposed policy & $\begin{array}{l}\text { Support for } \\
\text { speaker }\end{array}$ \\
\hline Agrees & & & \\
\hline Disagrees & 3 & 3 & 1 \\
\hline $\begin{array}{l}\text { No comment/ } \\
\text { neutral }\end{array}$ & & 6 & 8 \\
\hline
\end{tabular}

Table 3.6 Media response to Paulson's 18 November 2008 testimony

\section{February 2009: Secretary Geithner's historical analogy}

On succeeding Paulson as Treasury Secretary, Geithner's view of the crisis departed significantly from that of his predecessor. In introducing the Obama Administration's Financial Stability Plan, Geithner was more candid, taking the offensive type-3 posture. He called the state of the economy the worst economic crisis in generations - more complex than any the American financial system had ever faced. The crisis, he explained, had many and complex causes, which had accumulated over time. These included: policies that caused a huge global boom in credit; imprudent lending and borrowing; excessive executive remuneration; and poor regulation and oversight.

To make matters worse, he stated, when the crisis began governments had been too slow to act. Policy was always behind the curve and always chasing the escalating crisis. The force of government support had not been comprehensive or quick enough to withstand the deepening pressure brought on by the weakening economy. Further, the lack of clear criteria and conditions applied to government interventions caused investors to pull back from taking risks. The crisis in housing had had devastating consequences and the US Government should have moved more forcefully to limit the damage. 
Although Geithner did not explicitly mention the Bush Administration, he clearly apportioned blame to it for the causes and the deterioration of the crisis. Implicitly, he charged it with having acted too late, applied misguided policies and failed in its oversight and proper regulation of the financial markets.

His presentation of the new administration's crisis-management efforts took the form of a key announcement: that of the Economic Recovery Act - the Financial Stability Plan, which among other things, was aimed at restarting the flow of credit and imposing higher standards for transparency and accountability in the financial market. Geithner made a strong historical analogy in support of the plan. He referred to the Great Depression in the 1930s and to the Japanese experience in the 1990s to explain why government (implicitly, the Bush Administration) had failed to stem this crisis and what the Obama Administration intended to do differently. The secretary told Americans that the Obama Administration's efforts would be guided by the lessons of the preceding few months and by lessons of financial crises throughout history. In the United States in the 1930s and Japan in the 1990s, Geithner observed, crises lasted longer and caused greater damage because governments applied the brakes too early. For this reason, the administration's policy response would be comprehensive, forceful and might be sustained until recovery was firmly established.

Although the Treasury Secretary's rhetoric sounded forceful, it failed to elicit a positive public response. Six out of 10 of the articles reporting the speech disagreed with his policy proposal, although the main concerns were about how the administration would implement it rather than its content (Table 3.7). Much of the disagreement was directed at the Financial Stability Plan - an outgrowth of the Bush Government's Troubled Asset Relief Program (TARP), which was controversial. Geithner's involvement with the previous administration, however indirect, played into this sentiment.

\begin{tabular}{|l|l|l|l|}
\hline & Causality & Proposed policy & $\begin{array}{l}\text { Support for } \\
\text { speaker }\end{array}$ \\
\hline Agrees & & 6 & \\
\hline Disagrees & & 10 & \\
\hline $\begin{array}{l}\text { No comment/ } \\
\text { neutral }\end{array}$ & 6 & 1 & 17 \\
\hline
\end{tabular}

\section{Table 3.7 Media response to Geithner's 10 February 2009 speech}

No support for the secretary was expressed in the press coverage surveyed. Public opinion polls taken about a month later found Americans were divided on him, largely owing to his handling of the crisis when he was a senior Federal Reserve executive in the Bush Administration (Newport 2009). No comment was made about his version of the causality claims. Once again, this might be because 
a dominant framing of the causes of the crisis had already settled in the public mind.

\section{March 2009: Geithner's testimony to the House of Representatives}

Geithner's type-3 framing largely continued in written testimony to the House Financial Services Committee Hearing a month later. Geithner described the crisis as the most severe global financial crisis in generations. The financial system, he explained, had failed in basic and fundamental ways. Geithner saw the crisis in light of the fragility and instability of the whole financial system - and in light of the lack of proper government checks and balances, which resulted in compensation practices that rewarded short-term profits over long-term returns (for the whole catalogue of causation factors and his explanation, see the online appendix).

Again, Geithner endogenised the causes of the crisis, holding the Bush Administration to account for what he saw as government failure to regulate the markets. His management efforts concentrated on initiating a comprehensive reform: not modest repairs on the margins, but new rules of the game, which among other things would subject financial institutions that were critical to the functioning of the financial system to strong government oversight. The government's regulatory reform would cover four broad areas: systemic risk; consumer and investor protection; eliminating gaps in the regulatory structures; and international coordination (see the online appendix for a full list). Clearly, the bulk of Geithner's framing effort in this statement was focused on rallying support for the Obama Administration's reform agenda. Geithner failed, however, to convince the commentariat and the public once again. Only two out of 10 news stories that covered it in our sample supported the financial system reform plan. A range of sentiments and doubts was expressed-for example, the plan would not work, it was complicated and obscure, it certainly would not prevent the next crisis (Wessel 2009). One commentator put it colourfully:

One of the cool things about being Treasury Secretary is that you get your signature on dollar bills, giving them authority, defending their honor. Timothy Geithner's plan to save the struggling banking system probably does the opposite, throwing good money after bad to a banking system struggling under the weight of its own mistakes. The markets don't like it. The Dow dropped 382 points while bonds rallied as a port in a continuing storm. (Kessler 2009) 
And he continued:

The Treasury Secretary seems stuck on keeping the banks we have in place. But we don't need zombie banks overstuffed with nonperforming loans - ask the Japanese. Mr Geithner wants to 'stress test' banks to see which are worth saving. The market already has. Despite over a trillion in assets, Citigroup is worth a meager $\$ 18$ billion, Bank of America only $\$ 28$ billion. The market has already figured out that the banks and their accountants haven't fessed up to bad loans and that their shareholders are toast.

None of the press coverage engaged with Geithner's causality claims or expressed support or lack thereof for the Treasury Secretary. At this time, however, as mentioned above, public opinion was divided over him (Newport 2009). In a Gallup Poll taken on 27-29 March 2008 about American opinion of Treasury Secretary Geithner, 42 per cent approved of the way Geithner was doing his job, 40 per cent disapproved and 18 per cent had no opinion.

When compared, Geithner's two speech acts bear close similarity. His naming, explaining, accounting for and management of the crisis remained the same. This is because, perhaps, the speeches were only a few weeks apart, during which the crisis took no dramatic new turns. The differences of emphasis between the two speeches were due to the development of the administration's crisis-response repertoire, not to any change of view or stance in relation to the crisis.

\begin{tabular}{|l|l|l|l|}
\hline & Causality & Proposed policy & $\begin{array}{l}\text { Support for } \\
\text { speaker }\end{array}$ \\
\hline Agrees & & 2 & \\
\hline Disagrees & & 6 & \\
\hline $\begin{array}{l}\text { No comment/ } \\
\text { neutral }\end{array}$ & 12 & 4 & 12 \\
\hline
\end{tabular}

Table 3.8 Media response to Geithner's 26 March 2009 testimony

\section{Back to the Depression? Federal Reserve Chairman, Ben Bernanke}

Ben Bernanke had made a career as a scholar of the Great Depression before coming to the Federal Reserve. For Bernanke, the current crisis - a 'once-in-a-century' crisis, as his predecessor, Alan Greenspan, described it - offered an unique opportunity to put into practice what he had taught all his academic life: invoking a Depression-era law to lend money from the central bank to non-depository institutions (Bernanke 2008a). At the same time, in his running of the Fed, he had stayed within the 'Greenspan paradigm', which was 
now clearly discredited - as even Greenspan himself eventually admitted. This section attempts to analyse how the Federal Reserve Chairman framed the unfolding crisis and how his framing effort evolved with the change of administration.

\section{March 2008: Bernanke's response to Bear Stearns' collapse}

Geithner (who was then the President of the New York Federal Reserve) told Bernanke at 4am on 14 March 2008 of Bear's precarious position and the potential risk posed to the US financial system if it collapsed. Even after this dire prediction, however, in his speech that day on fostering sustainable homeownership, Bernanke did not name the financial troubles (PBS Frontline 2009). The closest he came to that was in a general statement about mortgage delinquency and foreclosure rates that had been rising substantially during the preceding year and a half. In terms of the crisis-exploitation model, at this time, Bernanke's stance in relation to the financial crisis was a firm type-1: believing that the financial system itself was not in crisis. His framing and management efforts focused on the mortgage market only. The high rate of delinquencies and foreclosures, he explained, was owed to the sharp deterioration in the performance of sub-prime mortgages, particularly those with adjustable-rate features. This, he continued, had its origins in the past quarter-century's advances in information technology, the development of credit-scoring techniques and the emergence of a large secondary market, which had significantly increased access to the mortgage market.

Bernanke defended existing mortgage market policies. Although much of his mortgage-related explanations of the crisis pointed to imprudent sub-prime lending practices, he insisted that sub-prime lending was responsible - except that it expanded credit to borrowers with less than perfect credit histories. His account of the troubles emphasised exogenous - market dynamics - factors, increased access to mortgages, amid irresponsible borrowing on the part of homeowners. His proposed responses focused on devising a comprehensive rule to protect consumers from unfair lending practices; to ensure that borrowers could afford their repayments; banning loan repayment penalties; and tight regulation of the practices of brokers.

Public reaction to the Bernanke speech was minimal. Of the press articles surveyed, most made no comment about the causality claim of the chairman. While five agreed with his policy proposal, seven did not, and most expressed no support for Bernanke. The majority of the commentators criticised the chairman for interfering with the working of the market-more especially, encouraging excessive risk taking among bankers by guaranteeing a federal bailout of collapsing banks (Irwin and Tse 2008). The lack of diverse reaction to the chairman's speech was perhaps due to the attention dedicated to Bear's liquidity issues and Bernanke's role in it. 


\begin{tabular}{|l|l|l|l|}
\hline & Causality & Proposed policy & $\begin{array}{l}\text { Support for } \\
\text { speaker }\end{array}$ \\
\hline Agrees & & 5 & 3 \\
\hline Disagrees & 5 & 7 & 2 \\
\hline $\begin{array}{l}\text { No comment/ } \\
\text { neutral }\end{array}$ & 8 & 1 & 8 \\
\hline
\end{tabular}

\section{Table 3.9 Media response to Bernanke's 14 March 2008 speech}

\section{December 2008: Bernanke's acknowledgment of crisis}

In this second speech, on 1 December 2008, Bernanke's posture had shifted significantly after it had become clear that the nation's financial system was in full-blown crisis (and a change of administration was imminent). At that time, more major banks had collapsed and the speed at which the crisis was unfolding had overwhelmed the Federal Reserve and Treasury's capacity to cope; he and Paulson had asked for money to bail out the system and the crisis had gone global. Besides the speech's title now containing the phrase 'financial crisis', Bernanke described the troubles as economic and financial challenges and an extraordinary period of financial turbulence. Of all Bush-era officials analysed here, Bernanke came closest to endogenising the causes of the crisis, by admitting that there was a serious internal weakness in the American financial system: the absence of well-defined procedures and authorities for dealing with the potential failure of systematically important non-bank financial institutions.

His proposed policy responses to the crisis concentrated on directing the Federal Reserve's efforts to offsetting its effects on credit conditions and the broader economy. Ironically, however, at this stage, Bernanke might have not fully come to terms with the fact that the crisis had already affected the broader economy. The chairman outlined interest rate cuts, the Emergency Economic Stabilisation Act and systemic risk minimisation as the few tools at the disposal of the Federal Reserve to fight the crisis.

Bernanke acknowledged weaknesses in the US financial system, but at the same time, he insisted that by way of historical comparison, the Federal Reserve's action stood out as exceptionally rapid and proactive. That effort was not particularly successful. As Table 3.10 reveals, the speech received comparatively little coverage and the tone of the commentaries it did receive was either neutral or negative. 


\begin{tabular}{|l|l|l|l|}
\hline & Causality & Proposed policy & $\begin{array}{l}\text { Support for } \\
\text { speaker }\end{array}$ \\
\hline Agrees & & & \\
\hline Disagrees & 1 & 2 & \\
\hline $\begin{array}{l}\text { No comment/ } \\
\text { neutral }\end{array}$ & 4 & 3 & 5 \\
\hline
\end{tabular}

\section{Table 3.10 Media response to Bernanke's 1 December 2008 speech}

\section{February 2009: Bernanke after the presidential transition}

Bernanke's third speech analysed in this chapter was chosen from the series he delivered after Obama had been sworn in as president. Obama took office with a series of policy proposals and measures focused on the crisis and other issues. Despite these, Bernanke's type-2 posture prevailed. He fully acknowledged that the economy was in crisis and recession, describing the time as extraordinarily challenging for the global economy and for economic policymakers - not least for central banks such as the Federal Reserve. Bernanke stopped short of explaining or accounting for the crisis and shifted to assuring Americans of the steps the Federal Reserve would take to restore financial stability and economic prosperity. Such efforts, he stated, would be directed towards easing credit through improving the functioning of credit markets and increasing the supply of credit to households and markets. He said that these measures would break with previous efforts that had been geared towards influencing short-term interest rates, which proved insufficient to overcome the effects of the crisis on credit conditions and the broader economy.

\begin{tabular}{|l|l|l|l|}
\hline & Causality & Proposed policy & $\begin{array}{l}\text { Support for } \\
\text { speaker }\end{array}$ \\
\hline Agrees & & & \\
\hline Disagrees & & 1 & \\
\hline $\begin{array}{l}\text { No comment/ } \\
\text { neutral }\end{array}$ & 7 & 6 & 7 \\
\hline
\end{tabular}

Table 3.11 Media response to Bernanke's 18 February 2009 speech

\section{March 2009: Bernanke acknowledges internal factors}

In March 2009, as Federal Reserve chief in the new Obama Administration, Bernanke remained in the type-2 position. He described the crisis as the worst since the 1930s. While acknowledging that the fundamental causes of the crisis remained in dispute, the chairman explained that the crisis was a result of the 1990s' global imbalances in trade and capital flows. According to Bernanke, these had been caused by the chronic lack of savings relative to investment in 
the United States and other industrial economies, combined with extraordinary increases in savings relative to investment in many emerging-market nations. As a result, he maintained, the United States had experienced large capital inflows for more than a decade even as real interest rates remained low.

The risk-management system of the private sector and government oversight of the financial sector in the United States, Bernanke said, failed to ensure that the inrush of capital was prudently invested. This resulted in the powerful reversal in investor sentiment and seizing up of credit markets, hence precipitating a sharp downturn in the global economy. By way of explanation, Bernanke showed some degree of consistency with Obama's and Geithner's framing attempts in accounting for the crisis. As well as acknowledging the role of endogenous factors, he pointed to the failures of government in harnessing the inflow of capital - a failure that caused the crisis.

Media reaction remained consistently indifferent to Bernanke's third and fourth framing attempts analysed here (Tables 3.10 and 3.11). Of the 16 press articles surveyed, the overwhelming majority made no comment about the chairman's causality claim. All but one made no comment about continued support for him. Opinion about his proposed policy was equally divided. Public opinion polls, however, found that the chairman's approval rating averaged 71 per cent- - better than the President's and his Treasury Secretary's (Izzo 2009).

\section{Conclusions: the limits of crisis management by speech}

For the Bush Administration, the political and policy implications of the framing contest regarding the financial crisis were disastrous. The administration's handling of the crisis was widely depicted as failing to grasp the nature and severity of the problems in time. President Bush's rhetoric failed to stem this tide, perhaps owing as much to his pre-existing credibility deficit as to his words and deeds in the current crisis. Bush, Paulson and Bernanke all took a type-1 stance at the early stage of the crisis, denying that the economic woes were more than incidental and self-correcting. Even after they switched to a type-2 posture, which implied acknowledgment of the crisis, they never regained control of the discourse.

Because the administration had initially insisted that there was no crisis, it did not see the need for a wholesale policy paradigm shift. Rather, it focused on ad-hoc, reactive measures such as the invocation of the Great Depression-style law that allowed the Federal Reserve to lend to non-banks and the bailout of one bank after another. These moves were aimed at aiding the process of market stabilisation. As we saw, this proved unpopular in the media and among the American public.

Until September 2008, Bush's rhetoric focused on talking up the economy and talking down the crisis. This stood in marked contrast with the pattern in his 
economic rhetoric during most of his first term, when he systematically talked down the economy in order to mobilise support for a series of unprecedented tax cuts, which he defended as a much-needed economic stimulus (Wood 2007). Bush's consistent stance during this period was one of 'it ain't broke, so why fix it'. For example, in his March 2008 address to the Economic Club of New York, the President said he disagreed with the idea of massive government intervention in the event of periodic instances of market 'stress' (Bush 2008a). When later in the year he bowed to the inevitable and started acknowledging the severity of the crisis, Bush's preference for minimal government intervention in the economy had to give way. The limited extent of his stimulus policy, however, betrayed his continued aversion to a more interventionist stance.

The administration came closer than ever to making a deeper policy change after shifting posture to type-2 when it pushed for the enactment of the Emergency Economic Stabilization Act (an economic stimulus package), which authorised Treasury to spend $\$ 700$ billion to undertake a system-wide rescue of the American financial markets - to buy toxic assets, especially the mortgage-backed securities (Paulson 2008b). The scope of the stimulus plan, which covered mainly the private sector, especially the financial markets, signalled the administration's willingness to relax its beliefs in government non-interference in, and deregulation of, the financial markets. It also demonstrated, however, its unwillingness to make a real policy paradigm shift - for example, by adopting a new regulatory regime for financial markets. This was especially true for Bush and Paulson, as both strongly believed in market discipline and freedom and were anti-regulation (PBS Frontline 2009).

Obama's economic policy philosophy departed from Bush's. In his State of the Nation Address to a Joint Session of Congress in February 2009, Obama rejected the neo-classical economic doctrine concerning the need for small government (Obama 2009b). Before his election, Obama had already emphasised his belief that a radical shift in policy was called for-one that featured stronger government regulation and oversight of key financial and economic institutions, as well as more direct public investment (Obama 2008). Once president, Obama ironically followed in Bush's rhetorical footsteps by talking down the economy (more specifically, talking up the magnitude and institutional depth of the crisis) in order to mobilise support for his economic reform agenda-only the American Recovery and Reinvestment Plan, which became law in February 2009, was a quite different reform agenda from the one pursued by Bush during 2001-05. Combining economic stimulus with policy innovation, the plan's scope was broad based and far reaching, including major investments in the areas of energy, health care, education and infrastructure and heightening government regulation of the economy. 
The extent to which Obama succeeded, as measured by the public opinion surveyed in the earlier part of the chapter, should not be overstated. First, President Bush was totally beleaguered as he prepared to exit office, whereas Obama had come to office with the energy of a new leader, not least on the promise of change in areas such as health care, education and energy, which large segments of the electorate had wanted 'fixed'. To some degree, the escalation of the financial crisis during the campaign was a political windfall for Obama, as it enabled him to develop an additional rationale for policy claims that had already struck a positive chord in the public anyway. Taking the offensive type-3 stance on the financial crisis from the outset, President Obama's crisis rhetoric acknowledged not just the role of unscrupulous financial trading on Wall Street, it put the emphasis on his predecessor's economic philosophies. Bush's attempt at defending his administration's record came late and was fatally flawed because of his declining popularity and the relentless avalanche of bad tidings about the economy.

There was a significant level of consistency between Obama's and Geithner's framing efforts during the early months of 2009. The two appeared to talk in unison in order to 'sell' the Obama Administration's change agenda. The differences were only of degree, not of kind. Once in office, Obama refrained from direct attacks on his predecessor's record, yet Geithner's framing directed blame squarely on the Bush Administration - not only for causing the crisis, but for failing to act early and decisively. His claims were blunt: the crisis accumulated over time through government policies that encouraged a global credit boom; and when the crisis began, the government response had been reactive, slow and incomprehensive.

The only one among the three office-holders to hold his position throughout, Bernanke charted his own rhetorical course during the crisis. His speeches did not betray any attempt to explicitly align his rhetoric with that of the Bush and later the Obama Administrations. Nor should such attempts be expected, given Bernanke's statutory independence. As observed earlier, Bernanke changed stance only once, from type-1 to type-2, nearly halfway through the unfolding of the global financial crisis in the period under study. Thereafter, the Federal Reserve chief consistently maintained the type-2 frame. After he had convinced himself that the current crisis was real and bigger than he had originally imagined, Bernanke, the scholar of the Great Depression, brought to bear his knowledge of its (mis-)management on his ideas about the unfolding financial crisis. It provided him with a wry opportunity: to test his hitherto untested academic belief that financial crises of this magnitude were manageable by capital injections from central banks.

Overall, this study lends some support to the notion that when major disruptive events such as the global financial crisis occur, public leaders are presented with 
an opportunity to reconsider their policy stances, and with a 'framing contest' that has potentially far-reaching political consequences. In the case of the United States in 2008 and 2009, the unfolding economic crisis significantly changed the economic policy and political landscapes, which started with the campaign rhetoric of John McCain and Barack Obama, graduated to partisan politicking between the Democrats and the Republicans and ended with the United States adopting major policy reforms that broke completely with the past.

The path to reform was paved by Obama and Geithner's crisis rhetoric, but not just theirs: there was an avalanche of media diagnosis of this crisis that was supporting their dire characterisations of the crisis and its causes. When it came to selling the idea that one - and only one - set of policies was best suited to combat the crisis, however, opinion was much more divided, and the public pronouncements of the new administration went only so far in carrying the day. In the end, it was probably the pressure-cooker effect of the escalating crisis itself that contributed as much as any other factor to the relatively quick success of Obama's arm-twisting of Congress to get his stimulus plan passed.

\section{References}

Audit Bureau of Circulations 2009, US Newspaper, 31 March, Audit Bureau of Circulations, viewed 28 April 2009, $<$ http://www.accessabc.com/index.html>

Baker, P. 2008, 'On Wall Street, the President steers clear of recession', The Washington Post, 15 March, viewed 12 April 2009, <http://www.washingtonpost.com/wp-dyn/content/article/ 2008/03/14/AR2008031401537.html>

Bernanke, B. 2008a, Fostering sustainable homeownership, Speech to Community Reinvestment Coalition Annual Meeting, United States Federal Reserve, Washington, DC, 14 March, viewed 30 April 2009, <http://www.federalreserve.gov/newsevents/speech/bernanke/20080314a.htm>

Bernanke, B. 2008b, Federal Reserve policies in the financial crisis, Speech, United States Federal Reserve, 1 December, viewed 30 April 2009, $<$ http://www.federalreserve.gov/newsevents/speech/bernanke/2008120la.htm>

Bernanke, B. 2009a, Federal Reserve policies to ease credit and their implications for the Fed's balance sheet, Speech, United States Federal Reserve, 18 February, viewed 29 April 2009, $<$ http://www.federalreserve.gov/newsevents/speech/bernanke20090218a.htm>

Bernanke, B. 2009b, Financial reform to address systemic risk, Speech to the Council on Foreign Relations, United States Federal Reserve, Washington, DC, 10 March, viewed 29 April 2009, <http://www.federalreserve.gov/newsevents/speech/bernanke20090310a.htm> 
Boin, A., 't Hart, P. and McConnell, A. 2009, 'Crisis exploitation: political and policy impacts of framing contests', European Journal of Public Policy, vol. 16, no. 1, pp. 81-106.

Burrough, B. 2008, 'Bringing down Bear Stearns', Vanity Fair, August, viewed 20 April 2009, <http://www.vanityfair.com/politics/features/2008/08/ bear_stearns200808?printable.htm>

Bush, G. W. 2008a, 'Address to the Economic Club of New York, New York', Presidential Rhetoric, 14 March, viewed 30 April 2009, <http://www.presidentialrhetoric.com/speeches/03.14.08.print.html>

Bush, G. W. 2008b, 'The economy and the bailout: primetime address to the nation', Presidential Rhetoric, 24 September, viewed 29 April 2009, <http://www.presidentialrhetoric.com/speeches/09.24.08.print.html>

Chomsisengphet, S. and Pennington-Cross, A. 2006, 'The evolution of the subprime mortgage market', Federal Reserve of St Louis Review, vol. 88, no. 1, pp. 31-56.

Collins, G. 2008, 'George speaks, badly', New York Times, 15 March, viewed 12 April 2009, <http://www.nytimes.com/2008/03/15/opinion/15collins.html>

Federal Insurance Deposit Corporation (FIDC) 2009, Failed Bank List, Federal Insurance Deposit Corporation, viewed 30 May 2009, <http://www.fdic.gov/bank/individual/failed/banklist.html>

Gallup Organization 2008, Gallup Poll, 14 March, Gallup Organization, viewed 20 May 2009, <http://www.gallup.com/video/104983/ Bush-Approval-Static-Congress-Sinks-Further.aspx $>$

Geithner, T. 2009a, Secretary Geithner introduces financial stability plan, Press release, United States Treasury, 10 February, viewed 29 April 2009, $<$ http://www.treas.gov/press/releases/tg18.htm>

Geithner, T. 2009b, Written testimony to the House Financial Services Committee Hearing, United States Treasury, 26 March, viewed 29 April 2009, $<$ http://www.treas.gov/press/releases/tg71.htm>

't Hart, P., Tindall, K. and Brown, C. 2009, 'Crisis leadership of the Bush presidency: advisory capacity and presidential performance in the acute stages of the 9/11 and Katrina crises', Presidential Studies Quarterly, vol. 39, no. 3, pp. 472-91.

Irwin, N. and Tse, T. M. 2008, 'Fed comes to rescue as Wall St giant slips; Bear Stearns gets emergency funds via JP Morgan', The Washington Post, 15 March, viewed 26 April 2009, $<$ http://www.washingtonpost.com/wp-dyn/content/article/ 2008/03/14/AR2008031401617.html> 
Izzo, P. 2009, 'Economists give Obama and Geithner low grades', The Wall Street Journal, 12 March, viewed 26 April 2009, $<$ http://online.wsj.com/article/SB123671107124286261.html>

Jones, J. 2008, 'Bush's approval rating drops to new low of 27\%', Gallup Poll, 30 September, Gallup Organization, viewed 9 May 2009, <http://www.gallup.com/poll/110806/ Bushs-Approval-Rating-Drops-New-Low-27.aspx?version=print.html> Jones, J. 2009, 'Obama approval rating increases to 67\%', Gallup Poll,

27 February, Gallup Organization, viewed 30 May 2009, $<$ http://www.gallup.com/poll/116224/Obama-Approval-Rating-Increases.aspx> KDKA-TV 2008, "Timeline: "US credit crunch and financial failures"”, , KDKA-TV CBS, 15 September, viewed 9 May 2009, $<\mathrm{http}: / / \mathrm{kdka} . c o m /$ business/credit.crisis.timeline.2.818699.html>

Kessler, A. 2009, 'Why markets dissed the Geithner plan', The Wall Street Journal, 11 February, viewed 12 April 2009, $<$ http://online.wsj.com/article/SB123431465155370931.html>

Kregel, J. 2008, Changes in the US financial system and the sub-prime crisis, Working Paper, no. 530 (August), The Levy Economic Institute of Bard College.

Morales, L. 2009, 'Obama speech bolsters confidence for many Americans', Gallup Poll, 26 February, Gallup Organization, viewed 25 April 2009, $<$ http://www.gallup.com/poll/116125/ obama-speech-bolsters-confidence-americans.aspx $>$

New York Times 2008, 'Getting to yes - readers' comments', The New York Times, 19 November, viewed 12 April 2009, $<$ http:/community.nytimes.com/comments/www.nytimes.com/ 2008/11/19/opinion/19wed 1.html>

Newport, F. 2009, 'Americans divided on Treasury Secretary Geithner', Gallup Poll, 30 March, Gallup Organization, viewed 12 April 2009, <http://www.gallup.com/poll/117175/ Americans-Divided-Treasury-Secretary-Geithner $>$

Obama, B. 2008, 'An economic proposal', Presidential Rhetoric, 16 September, viewed 30 April 2009, $<$ http://www.presidentialrhetoric.com/campaign2008/obama/09.16.08.html>

Obama, B. 2009a, 'Remarks on the economy and executive pay', Presidential Rhetoric, 4 February, viewed 29 April 2009, $<$ http://www.presidentialrhetoric.com/speeches/02.04.09.print.html> 
Obama, B. 2009b, 'The state of the nation: address to the Joint Session of Congress', Presidential Rhetoric, 24 February, viewed 30 April 2009, <http://www.presidentialrhetoric.com/speeches/02.24.09.html>

Paletta, D. 2008, 'Politics \& economics: FHA may aid those "underwater" on loans', The Wall Street Journal, 31 March, viewed 30 April 2009, $<$ http://www.realestatejournal.com/buysell/mortgages/20080331-paletta.html>

Paulson, H. 2008a, Remarks by Secretary Henry M. Paulson, jr, on financial and housing markets, Press release, United States Treasury, 26 March, viewed 30 April 2009, <http://www.treas.gov/press/releases/hp887.htm>

Paulson, H. 2008b, Paulson statement on Emergency Economic Stabilization Act, Press release, United States Treasury, 3 October, viewed 26 April 2009, $<$ http://www.treas.gov/press/releases/hp1175.htm>

Paulson, H. 2008c, On the implementation of the Emergency Economic Stabilization Act, Press release, United States Treasury, 18 November, viewed 12 April 2009, <http://www.treas.gov/press/releases/hpl279.htm>

PBS Frontline 2009, 'Inside the meltdown', PBS Frontline, 17 February, viewed 12 April 2009, <http://www.pbs.org/wgbh/pages/frontline/meltdown/view/>

Saad, L. 2008, 'US financial rescue plan wins slim public support', Gallup Poll, 6 October, Gallup Organization, viewed 9 May 2009, $<$ http:www.gallup.com/poll/110977/

US-Financial-Rescue-Plan-Wins-Slim-Public-Support.aspx?version.htm>

Thomas, L. 2008, 'Run on Wall St bank spurs US-backed rescue', The New York Times, 15 March, viewed 12 April 2009, <http://www.nytimes.com/2008/03/15/business/15bear.html>

Uchitelle, L. 2008, 'A political comeback: supply-side economics', The New York Times, 26 March, viewed 24 May 2009, <http://www.nytimes.com/2008/03/26/business/26supply.html?_r=l>

Washington Post 2008, 'Troubled TARP, keep the bailout focused on job one: restoring bank solvency', The Washington Post, 19 November, viewed 12 April 2009, $<$ http://www.washingtonpost.com/wp-dyn/content/article/ 2008/11/18/AR2008111803021.html>

Wessel, D. 2009, 'US new capital: Geithner's plan carries a new set of risks', The Wall Street Journal, 26 March, viewed 26 April 2009, <http://online.wsj.com/article/SB123800845407840625.html>

Wood, B. D. 2007, The Politics of Economic Leadership: The causes and consequences of presidential rhetoric, Princeton University Press, Princeton. 